medRxiv preprint doi: https://doi.org/10.1101/2020.06.26.20141176; this version posted June 28, 2020. The copyright holder for this preprint (which was not certified by peer review) is the author/funder, who has granted medRxiv a license to display the preprint in perpetuity.

\title{
Association study of DNAJC13, UCHL1, HTRA2, GIGYF2 and EIF4G1 with Parkinson's
}

\section{disease}

Prabhjyot Saini ${ }^{1,2}$, Uladzislau Rudakou ${ }^{1,2}$, Eric $\mathrm{Yu}^{1,2}$, Jennifer A. Ruskey ${ }^{1,2}$, Farnaz Asayesh ${ }^{1,2}$, Sandra B. Laurent ${ }^{1,2}$, Dan Spiegelman ${ }^{1,3}$, Stanley Fahn ${ }^{4}$, Cheryl Waters ${ }^{4}$, Oury Monchi ${ }^{5,6}$, Yves Dauvilliers ${ }^{7}$, Nicolas Dupré ${ }^{8,9}$, Lior Greenbaum ${ }^{10,11,12}$, Sharon Hassin-Baer ${ }^{10,13}$, Alberto J. Espay $^{14}$, Guy A. Rouleau ${ }^{1,2,3}$, Roy N. Alcalay ${ }^{4,15}$, Edward A. Fon ${ }^{1,2}$, Ronald B. Postuma ${ }^{1,3}$, Ziv Gan-Or ${ }^{1,2,3}$

Affiliations

${ }^{1}$ Montreal Neurological Institute, McGill University, Montréal, QC, H3A 1A1, Canada

${ }^{2}$ Department of Human Genetics, McGill University, Montréal, QC, H3A 1A1, Canada

${ }^{3}$ Department of Neurology and neurosurgery, McGill University, Montréal, QC, H3A 0G4, Canada, Canada

${ }^{4}$ Department of Neurology, College of Physicians and Surgeons, Columbia University Medical Center, 710 West 168th Street, New York, NY, 10032-3784 USA.

${ }^{5}$ Department of Clinical Neurosciences and Department of Radiology, University of Calgary, 2500 University Drive NW Calgary, Alberta, T2N 1N4, Canada;

${ }^{6}$ Cumming School of Medicine, Hotchkiss Brain Institute, Calgary, 3330 Hospital Drive NW Calgary, Alberta, T2N 4N1 Canada.

${ }^{7}$ National Reference Center for Narcolepsy, Sleep Unit, Department of Neurology, Gui-deChauliac Hospital, CHU Montpellier, University of Montpellier, Inserm U1061, Montpellier, France.

${ }^{8}$ Division of Neurosciences, CHU de Québec, Université Laval, 2705 Laurier Boulevard, Quebec City, Quebec G1V 4G2, Canada

${ }^{9}$ Department of Medicine, Faculty of Medicine, Université Laval, 1050 Avenue de la Médecine, Québec, QC G1V 0A6, Canada

${ }^{10}$ Sackler Faculty of Medicine, Tel Aviv University, Tel Aviv, Israel

${ }^{11}$ Danek Gertner Institute of Human Genetics, Sheba Medical Center, Tel Hashomer, Israel.

${ }^{12}$ Joseph Sagol Neuroscience Center, Sheba Medical Center, Tel Hashomer, Israel

${ }^{13}$ The Movement Disorders Institute, Department of Neurology, Sheba Medical Center, Tel Hashomer, Israel.

${ }^{14}$ Gardner Family Center for Parkinson's Disease and Movement Disorders, Department of Neurology, University of Cincinnati, 3113 Bellevue Ave, Cincinnati, OH 45229, USA.

${ }^{15}$ Taub Institute for Research on Alzheimer's Disease and the Aging Brain, College of Physicians and Surgeons, Columbia University Medical Center, 710 W 168th St 3, New York, NY 10032, USA.

Corresponding author:

Ziv Gan-Or

Department of Neurology and Neurosurgery 
medRxiv preprint doi: https://doi.org/10.1101/2020.06.26.20141176; this version posted June 28, 2020. The copyright holder for this preprint (which was not certified by peer review) is the author/funder, who has granted medRxiv a license to display the preprint in perpetuity.

It is made available under a CC-BY 4.0 International license.

\section{McGill University}

1033 Pine Avenue, West, Ludmer Pavilion, room 312

Montreal, QC, H3A 1A1,

Email: ziv.gan-or@mcgill.ca 
medRxiv preprint doi: https://doi.org/10.1101/2020.06.26.20141176; this version posted June 28, 2020. The copyright holder for this preprint (which was not certified by peer review) is the author/funder, who has granted medRxiv a license to display the preprint in perpetuity.

It is made available under a CC-BY 4.0 International license .

\begin{abstract}
Rare mutations in genes originally discovered in multi-generational families have been associated with increased risk of Parkinson's Disease (PD). The involvement of rare variants in DNAJC13, UCHL1, HTRA2, GIGYF2 and EIF4G1 loci have been poorly studied or produced conflicting results across cohorts. However, they are still being often referred to as "PD-genes" and used in different models. To further elucidate the role of these five genes in PD, we fully sequenced them using molecular inversion probes in 2,408 PD patients and 3,444 controls from 3 different cohorts. A total of 788 rare variants were identified across the five genes and three cohorts. Burden analyses and optimized sequence Kernel association tests revealed no significant association between any of the genes and PD after correction for multiple comparisons. Our results do not support an association of the five tested genes with PD. Combined with previous studies, it is unlikely that any of these genes plays an important role in PD. Their designation as "PARK" genes should be reconsidered.
\end{abstract}

Keywords: Parkinson's Disease, DNAJC13, UCHL1, HTRA2, GIGYF2, EIF4G1, Ashkenazi Jewish, French-Canadian, SKAT-O 
medRxiv preprint doi: https://doi.org/10.1101/2020.06.26.20141176; this version posted June 28, 2020. The copyright holder for this preprint (which was not certified by peer review) is the author/funder, who has granted medRxiv a license to display the preprint in perpetuity.

It is made available under a CC-BY 4.0 International license.

\subsection{Introduction}

Parkinson's disease (PD) is clinically characterized by progressive movement disability, mainly bradykinesia, tremor and muscle rigidity, often accompanied by other motor and non-motor symptoms (Jankovic, 2008). Common genetic variants of PD have largely been discovered through genome-wide association studies (GWAS), and to date 92 independent risk variants in 80 loci have been identified (Foo et al., 2020; Nalls et al., 2019). Other types of studies, including linkage and next generation sequencing studies in families with multiple affected family members with PD or other forms of Parkinsonism led to the identification of familial PDassociated genes, many of them have received the alias PARK (e.g. PARK1, PARK2, etc.) (Deng et al., 2018).

Five suggested PD-causing genes identified through family studies and cohorts, UCHL1 (Lincoln et al., 1999), GIGYF2 (Lautier et al., 2008), HTRA2 (Strauss et al., 2005), EIF4G1 (Chartier-Harlin et al., 2011), and DNAJC13 (Vilariño-Güell et al., 2013), (also termed PARK5, PARK11, PARK13, PARK18 and PARK21, respectively) have been under scrutiny regarding their association with PD. Their discovery shares several similarities, including the presumed role of loss-of-function, missense mutations and dominant heritability (Nalls et al., 2019). Subsequent studies, in many cases, failed to replicate the association of these genes with PD (Bartonikova et al., 2018; Gagliardi et al., 2018; Kruger et al., 2011; Nuytemans et al., 2013; Sun et al., 2014). However, ongoing studies, including those using cellular and animal models, continue to refer to these genes as PD-associated genes, and to invoke their function in PDrelated mechanisms (Chen et al., 2018; Tran et al., 2018).

The primary goal of the present study is to use large cohorts of PD patients $(n=2,382)$ and controls $(n=3,411)$ to further examine the potential role of rare variants in these genes in PD. 
medRxiv preprint doi: https://doi.org/10.1101/2020.06.26.20141176; this version posted June 28, 2020. The copyright holder for this preprint (which was not certified by peer review) is the author/funder, who has granted medRxiv a license to display the preprint in perpetuity.

It is made available under a CC-BY 4.0 International license .

\subsection{Materials \& Methods}

\subsection{Populations}

Full sequencing of UCHL1, HTRA2, GIGYF2, EIF4G1 and DNAJC13 was performed in 2,408 PD patients and 3,444 controls from three different cohorts: a) McGill cohort, including 855 patients and 2,441 controls from Quebec, Canada and Montpellier, France, all of European origin, b) Columbia cohort, including 963 patients and 508 controls from New York, Mainly of European or Ashkenazi-Jewish (AJ) ancestry, and c) Sheba cohort, including 590 patients and 495 controls of AJ ancestry collected at Sheba Medical Center, Israel. Demographic details on these cohort can be found in Supplementary Table S1. All subjects were consecutively recruited, and patients were diagnosed by a movement disorders specialist according to the UK Brain Bank Criteria (Hughes et al., 1992) or the MDS criteria (Postuma et al., 2015). All patients and controls signed informed consent at enrollment and the study protocols were approved by the institutional review.

\subsection{Genetic analysis}

The entire coding regions of the five genes, including 5' and 3' untranslated regions (UTRs) and exon-intron boundaries, were captured using molecular inversion probes (MIPs), followed by sequencing as previously described (Ross et al., 2016). Supplementary Table S2 includes all the MIPs used to capture and sequence GIGYF2, HTRA2, DNAJC13, UCHL1, EF4G1, and the full protocol is available upon request. The library was sequenced using Illumina HiSeq 2500/4000 platform at the McGill University and Genome Quebec Innovation Centre. Reads were mapped to the human reference genome (hg19) with Burrows-Wheeler Aligner (Li and Durbin, 2009). Alignment, quality control and variant calling was performed with Genome Analysis Toolkit (GATK, v3.8) (McKenna et al., 2010) and PLINK software v1.9 (Purcell et al., 2007) and ANNOVAR was used for annotation (Wang, K. et al., 2010). Minor allele frequency from 
medRxiv preprint doi: https://doi.org/10.1101/2020.06.26.20141176; this version posted June 28, 2020. The copyright holder for this preprint (which was not certified by peer review) is the author/funder, who has granted medRxiv a license to display the preprint in perpetuity.

It is made available under a CC-BY 4.0 International license.

European and Ashkenazi Jewish ancestries were extracted from the public database Genome Aggregation Database (GnomAD) (Lek et al., 2016). The variants were filtered based on a minimum read depth $\geq 30 X$, a genotype quality (GQ) $\geq 30$, genotyping rate cut-off for individuals was $90 \%$, missingness difference between patients and controls was set at $p=0.05$ and adjusted by Bonferroni correction, proportion of the reads with alternative alleles $\geq 25 \%$, and deviation from Hardy-Weinberg equilibrium was set at $p=0.001$.

\subsection{Statistical Analyses}

Burden and optimized Sequence Kernel Association Test (SKAT-O, R package) (Lee et al., 2012) were used to analyze the joint effects of rare variants (minor allele frequency, MAF $\leq 0.01)$. These analyses were performed on five groups of variants: a) all rare variant, b) functional variants, defined as all nonsynonymous, splice-site, frameshift and stop variants, c) loss of function variants, defined as splice-site, frameshift and stop variants, d) nonsynonymous variants and e) variants with Combined Annotation Dependent Depletion (CADD) score of $>12.37$, which is the threshold for the top $2 \%$ of predicted most deleterious variants. We repeated the analysis twice, at coverage of $>30 \mathrm{X}$ and at coverage of $>50 \mathrm{X}$, to ensure high quality and confidence in the variant calls. Bonferroni correction for multiple comparisons considered the number of genes (five), number of cohorts (three), number of depth coverage (two) and number of statistical tests (two), which set the threshold for statistical significance at $\mathrm{p}<0.00083$. 
medRxiv preprint doi: https://doi.org/10.1101/2020.06.26.20141176; this version posted June 28, 2020. The copyright holder for this preprint (which was not certified by peer review) is the author/funder, who has granted medRxiv a license to display the preprint in perpetuity.

It is made available under a CC-BY 4.0 International license .

\subsection{Results}

\subsection{Quality control and variants identified}

The average coverage of the five genes range between $237 \mathrm{X}-1592 \mathrm{X}$ in the different cohorts, and the percentages of read depth of the targeted genes were $93.07 \%$ and $88.76 \%$ of the bases covered by at least 20X and 50X respectively, and the coverage of each gene was nearly identical in the three cohorts (coverage depth and average coverage for each gene in each cohort are detailed in Supplementary Table S3). We identified a total of 788 rare variants in these five genes. The distribution of rare variants across the coding region and functional domains is available across cohorts and sequencing depth (Supplementary Table S4).

\subsection{Association of rare variants and risk of Parkinson's disease}

To further investigate whether rare variants in these five genes contribute to PD risk, we conducted a gene-based burden test and found no significant results within cohorts and depths across mutation type (Table 1). SKAT-O test for enrichment of all variant groups across the entire gene region in each cohort and sequencing depth suggested that DNAJC13 variants were nominally enriched in PD patients in the Sheba cohort $(\mathrm{p}=0.0426)$ and were driven by nonsynonymous variants $(\mathrm{p}=0.0002)$ (Table 1$)$. However, this association was driven by higher frequency of nonsynonymous variants in controls (1.9\%) than in PD patients (1.1\%, Supplementary Table S5), demonstrating that nonsynonymous variants in this gene are not associated with higher risk of PD. In all other four genes there were no statistically significant associations in any of the cohorts tested (Table 1). 
medRxiv preprint doi: https://doi.org/10.1101/2020.06.26.20141176; this version posted June 28, 2020. The copyright holder for this preprint (which was not certified by peer review) is the author/funder, who has granted medRxiv a license to display the preprint in perpetuity.

It is made available under a CC-BY 4.0 International license .

\subsection{Discussion}

Our study, which included full sequencing of UCHL1, GIGYF2, HTRA2, DNAJC13 and EIF4G1 in 3 cohorts, identified 788 rare variants $(\mathrm{MAF}<0.01)$ that are nonsynonymous, loss-of-function, pathogenic as predicted by CADD scores, or affect splicing in coding regions of the gene and splice sites. Our results do not support a role for any of these genes in PD.

Of the five genes, DNAJC13 in the Sheba cohort showed nominal association with controls driven by nonsynonymous variants with higher frequency in controls compared to PD cases. A previously reported variant, p.L1207W (Ross et al., 2016), was detected in all 3 cohorts, but had similar frequencies between cases and controls (Columbia), greater frequency in controls than cases (McGill) or were found exclusively in controls (Sheba, Supplementary Table S6-S8). The original DNAJC13 association were described in a large-multi-incident family of DutchGerman-Russian-Mennonite ancestry that presented with autosomal dominant PD, where a p.N855S coding variant only partially co-segregated with disease status. Since the original description, several studies have reported other genetic variants in Italian cohorts (p.R903K) (Gagliardi et al., 2018) and Taiwanese cohorts (p.G394V and p.R1382H), yet the pathogenicity of these variants has not been confirmed. In addition, other previously described variants did not segregate by disease (p.R1516H and p.L2170W) (Ross et al., 2016), and in cohorts with sparse number of probands with rare variants in DNAJC13 (Gagliardi et al., 2018; Lin et al., 2019). No other study was able to confirm the pathogenicity of the DNAJC13 p.N855S variant. Moreover, in the same Dutch-German-Russian-Mennonite family, another gene, TMEM230, has been reported to be associated with PD instead of DNAJC13. Similar to DNAJC13, TMEM230 had imperfect disease segregation within the family (Deng et al., 2016). These inconsistent results, 
medRxiv preprint doi: https://doi.org/10.1101/2020.06.26.20141176; this version posted June 28, 2020. The copyright holder for this preprint (which was not certified by peer review) is the author/funder, who has granted medRxiv a license to display the preprint in perpetuity.

It is made available under a CC-BY 4.0 International license .

together with the negative results in the current study and previous studies (Foo et al., 2014; Lorenzo-Betancor et al., 2015) call into question a role for DNAJC13 in PD.

The role of HTRA2 in PD was initially suggested as two missense variants (p.G399S and p.A141S) were reported to be associated with PD (Strauss et al., 2005). Subsequently, the p.G399S variant co-segregated with PD and essential tremor (ET) in a large Turkish family (Unal Gulsuner et al., 2014), providing further evidence of its potential role in PD. Additional variants were reported in Belgian (p.R404W) (Bogaerts et al., 2008), Chinese (IVS5+29T>A) (Wang, C.Y. et al., 2011), and Taiwanese (p.P143A) PD patients (Lin et al., 2011), yet without evidence for pathogenicity. Evidence for the p.G399S variant remains elusive even after several large-scale studies with PD in various populations worldwide (Kruger et al., 2011; Ross et al., 2008; Simon-Sanchez and Singleton, 2008). Moreover, the p.G399S mutations has been associated with ET, yet in subsequent studies of ET and PD, there was no significant evidence of an association of this variant with PD (He et al., 2017). Similar to DNAJC13, there are insufficient data to conclude that this gene is associated with PD.

Since the first description of the association of EIF4G1 variants (p.R1205H and p.A502V) with PD (Chartier-Harlin et al., 2011), numerous subsequent studies could not conclude that EIF4G1 variants caused or associated with PD (Nuytemans et al., 2013; Schulte et al., 2012; Siitonen et al., 2013; Tucci et al., 2012). It is possible that the p.R1205H variant is not highly penetrant, as it was found in the original study (Chartier-Harlin et al., 2011) and in another family where it co-segregated with PD (Nuytemans et al., 2013); however, it was also reported in three controls (Schulte et al., 2012). Ethnic differences could account for the lack of findings as these variants were not found in several Asian ethnicities (Chen et al., 2013; Li et al., 2013; Nishioka et al., 2014; Sudhaman et al., 2013; Zhao et al., 2013). Interestingly, in the 
medRxiv preprint doi: https://doi.org/10.1101/2020.06.26.20141176; this version posted June 28, 2020. The copyright holder for this preprint (which was not certified by peer review) is the author/funder, who has granted medRxiv a license to display the preprint in perpetuity.

It is made available under a CC-BY 4.0 International license.

present study, the p.R1205H variant was found exclusively in controls in the McGill and Columbia cohorts. Given the multiple negative results and the presence of the p.R1205H in multiple controls, EIF4G1 is unlikely to play a role in PD.

GIGYF2 was initially reported in a cohort composed of Italian and French PD patients (Lautier et al., 2008), yet subsequent studies in Portuguese and US cohorts did not find evidence of association with PD (Bras et al., 2009). Numerous additional studies, including in a different Italian cohort and multiple other ethnicities, also failed to identify an association of GIGYF2 variants with PD (Bartonikova et al., 2018; Bonetti et al., 2009; Di Fonzo et al., 2009; Guo et al., 2009; Huo et al., 2017; Lesage et al., 2010; Li et al., 2010; Meeus et al., 2011; Nichols et al., 2009; Samaranch et al., 2010; Tan et al., 2009; Tan and Schapira, 2010; Tian et al., 2012; Vilarino-Guell et al., 2009; Wang, L. et al., 2010; Wang, L. et al., 2011; Yang et al., 2019; Zhang et al., 2015; Zhang et al., 2009; Zimprich et al., 2009). It is therefore very unlikely that GIGYF2 is associated with PD.

The association of UCHLl was initially reported with the common p.S18Y variant (Lincoln et al., 1999), and while several studies initially supported this association (Maraganore et al., 2004; Ragland et al., 2009) other studies have failed to demonstrate that any UCHL1 variants are associated with increased risk of PD (Elbaz et al., 2003; Healy et al., 2006; Levecque et al., 2001; Mellick and Silburn, 2000; Momose et al., 2002; Satoh and Kuroda, 2001; Savettieri et al., 2001; Wang et al., 2002; Wintermeyer et al., 2000; Zhang et al., 2000). Since the UCHL1 p.S18Y is common, it should have been discovered in the large European and Asian GWASs (Foo et al., 2020; Nalls et al., 2019) yet it has not. In the present study, rare variants in UCHL1 also did not demonstrate any association with PD. Given with the lack of effect of common variants, $U C H L 1$ is unlikely to be involved in PD. 
medRxiv preprint doi: https://doi.org/10.1101/2020.06.26.20141176; this version posted June 28, 2020. The copyright holder for this preprint (which was not certified by peer review) is the author/funder, who has granted medRxiv a license to display the preprint in perpetuity.

It is made available under a CC-BY 4.0 International license.

Our study has several limitations, including the lack of age and sex matching between patients and controls. However, in the Columbia cohort the controls were older than the patients, whereas in the other two cohorts the controls were younger, yet no significant associations were found in any, suggesting that age did not affect the current results. In addition, it is possible that control subjects develop PD in the future, specifically in those cases where variants were found exclusively in controls. Since the risk of PD is about $1-2 \%$ in the control population, the effect on the results would likely be minor, even if a few individuals did develop PD. Lastly, despite being a large study, we cannot completely rule out that very rare variants or more common variants with a very small effect on risk could be involved in PD in one or more of five tested genes. The fact that many large studies, including GWASs, genotyping and sequencing studies have so far mostly failed to detect associations, makes this possibility seem unlikely.

Altogether, the present study and the survey of existing literature strongly indicate a lack of association of PD with UCHL1, HTRA2, GIGYF2, EIF4G1 and DNAJC13. The PARK aliases that these genes have received may lead to confusion and continue to inspire basic and clinical research as PD models. As the evidence suggests these genes are not associated with PD, we recommend removing the $P A R K$ designation off these genes. 
medRxiv preprint doi: https://doi.org/10.1101/2020.06.26.20141176; this version posted June 28, 2020. The copyright holder for this preprint (which was not certified by peer review) is the author/funder, who has granted medRxiv a license to display the preprint in perpetuity.

It is made available under a CC-BY 4.0 International license .

\section{Acknowledgements}

We thank the patients and control subjects for their participation in this study. This work was financially supported by the Michael J. Fox Foundation, the Canadian Consortium on Neurodegeneration in Aging (CCNA), the Canada First Research Excellence Fund (CFREF), awarded to McGill University for the Healthy Brains for Healthy Lives (HBHL) program and Parkinson Canada. The Columbia University cohort is supported by the Parkinson's Foundation, the National Institutes of Health [K02NS080915, and UL1 TR000040] and the Brookdale Foundation. GAR holds a Canada Research Chair in Genetics of the Nervous System and the Wilder Penfield Chair in Neurosciences. EAF is supported by a Foundation Grant from the Canadian Institutes of Health Research (FDN grant - 154301) and a Canada Research Chair (Tier 1) in Parkinson Disease. ZGO is supported by the Fonds de recherche du Québec - Santé (FRQS) Chercheurs-boursiers award and Parkinson Quebec, and by the Young Investigator Award by Parkinson Canada. The access to part of the participants for this research has been made possible thanks to the Quebec Parkinson's Network (http://rpq-qpn.ca/en/). We thank Daniel Rochefort, Helene Catoire, Clotilde Degroot and Vessela Zaharieva for their assistance.

\section{Conflict of Interest}

SF received consulting fees/honoraria for board membership (unrelated to the current study) from Retrophin Inc., Sun Pharma Advanced Research Co., LTD and Kashiv Pharma. CW received consulting fees/honoraria (unrelated to the current study) from US World Meds, Acadia, Lundbeck, Cynapsus, Acorda. ND received consultancy fees (unrelated to the current work) from Actelion Pharmaceuticals. SHB received consulting fees from Actelion Pharmaceuticals 
Ltd., Abbvie Israel, Robotico Ltd., Medtronic Israel, Medison Pharma Israel (unrelated to the current study). AJE received grant support from the NIH and the Michael J Fox Foundation; personal compensation as a consultant/scientific advisory board member for Abbvie, Neuroderm, Neurocrine, Amneal, Adamas, Acadia, Acorda, InTrance, Sunovion, Lundbeck, and USWorldMeds; publishing royalties from Lippincott Williams \& Wilkins, Cambridge University Press, and Springer; and honoraria from USWorldMeds, Acadia, and Sunovion. RNA received consultation fees (unrelated to the current study) from Biogen, Denali, Genzyme/Sanofi and Roche. EAF Received consulting fees (unrelated to the current study) from Inception Sciences. ZGO received consulting fees (unrelated to the current study) from Denali, Inception Sciences (now Ventus), Idorsia, Lysosomal Therapeutics Inc., Prevail Therapeutics, Deerfield, Neuron23 and Handl Therapeutics. All other authors report no conflict of interest. 
medRxiv preprint doi: https://doi.org/10.1101/2020.06.26.20141176; this version posted June 28, 2020. The copyright holder for this preprint (which was not certified by peer review) is the author/funder, who has granted medRxiv a license to display the preprint in perpetuity.

It is made available under a CC-BY 4.0 International license.

\section{References}

Bartonikova, T., Mensikova, K., Kolarikova, K., Vodicka, R., Vrtel, R., Otruba, P., Kaiserova, M., Vastik, M., Mikulicova, L., Ovecka, J., Sachova, L., Dvorsky, F., Krsa, J., Jugas, P., Godava, M., Bares, M., Janout, V., Hlustik, P., Prochazka, M., Kanovsky, P., 2018. New endemic familial parkinsonism in south Moravia, Czech Republic and its genetical background. Medicine 97(38), e12313.

Bogaerts, V., Nuytemans, K., Reumers, J., Pals, P., Engelborghs, S., Pickut, B., Corsmit, E., Peeters, K., Schymkowitz, J., De Deyn, P.P., Cras, P., Rousseau, F., Theuns, J., Van Broeckhoven, C., 2008. Genetic variability in the mitochondrial serine protease HTRA2 contributes to risk for Parkinson disease. Human mutation 29(6), 832-840.

Bonetti, M., Ferraris, A., Petracca, M., Bentivoglio, A.R., Dallapiccola, B., Valente, E.M., 2009. GIGYF2 variants are not associated with Parkinson's disease in Italy. Movement disorders : official journal of the Movement Disorder Society 24(12), 1867-1868; author reply 1868-1869.

Bras, J., Simon-Sanchez, J., Federoff, M., Morgadinho, A., Januario, C., Ribeiro, M., Cunha, L., Oliveira, C., Singleton, A.B., 2009. Lack of replication of association between GIGYF2 variants and Parkinson disease. Hum Mol Genet 18(2), 341-346.

Chartier-Harlin, M.C., Dachsel, J.C., Vilarino-Guell, C., Lincoln, S.J., Lepretre, F., Hulihan, M.M., Kachergus, J., Milnerwood, A.J., Tapia, L., Song, M.S., Le Rhun, E., Mutez, E., Larvor, L., Duflot, A., Vanbesien-Mailliot, C., Kreisler, A., Ross, O.A., Nishioka, K., Soto-Ortolaza, A.I., Cobb, S.A., Melrose, H.L., Behrouz, B., Keeling, B.H., Bacon, J.A., Hentati, E., Williams, L., Yanagiya, A., Sonenberg, N., Lockhart, P.J., Zubair, A.C., Uitti, R.J., Aasly, J.O., KrygowskaWajs, A., Opala, G., Wszolek, Z.K., Frigerio, R., Maraganore, D.M., Gosal, D., Lynch, T., Hutchinson, M., Bentivoglio, A.R., Valente, E.M., Nichols, W.C., Pankratz, N., Foroud, T., Gibson, R.A., Hentati, F., Dickson, D.W., Destee, A., Farrer, M.J., 2011. Translation initiator EIF4G1 mutations in familial Parkinson disease. Am J Hum Genet 89(3), 398-406.

Chen, S., Sanislav, O., Annesley, S.J., Fisher, P.R., 2018. Mitochondrial HTRA2 Plays a Positive, Protective Role in Dictyostelium discoideum but Is Cytotoxic When Overexpressed. Genes (Basel) 9(7).

Chen, Y., Chen, K., Song, W., Chen, X., Cao, B., Huang, R., Zhao, B., Guo, X., Burgunder, J., Li, J., Shang, H.-F., 2013. VPS35 Asp620Asn and EIF4G1 Arg1205His mutations are rare in Parkinson disease from Southwest China. Neurobiology of Aging 34(6), 1709.e17071709.e1708.

Deng, H., Wang, P., Jankovic, J., 2018. The genetics of Parkinson disease. Ageing Research Reviews $42,72-85$.

Deng, H.X., Shi, Y., Yang, Y., Ahmeti, K.B., Miller, N., Huang, C., Cheng, L., Zhai, H., Deng, S., Nuytemans, K., Corbett, N.J., Kim, M.J., Deng, H., Tang, B., Yang, Z., Xu, Y., Chan, P., Huang, B., Gao, X.P., Song, Z., Liu, Z., Fecto, F., Siddique, N., Foroud, T., Jankovic, J., Ghetti, B., Nicholson, D.A., Krainc, D., Melen, O., Vance, J.M., Pericak-Vance, M.A., Ma, Y.C., Rajput, A.H., Siddique, T., 2016. Identification of TMEM230 mutations in familial Parkinson's disease. Nat Genet 48(7), 733-739. 
medRxiv preprint doi: https://doi.org/10.1101/2020.06.26.20141176; this version posted June 28, 2020. The copyright holder for this preprint (which was not certified by peer review) is the author/funder, who has granted medRxiv a license to display the preprint in perpetuity. It is made available under a CC-BY 4.0 International license .

Di Fonzo, A., Fabrizio, E., Thomas, A., Fincati, E., Marconi, R., Tinazzi, M., Breedveld, G.J., Simons, E.J., Chien, H.F., Ferreira, J.J., Horstink, M.W., Abbruzzese, G., Borroni, B., Cossu, G., Dalla Libera, A., Fabbrini, G., Guidi, M., De Mari, M., Lopiano, L., Martignoni, E., Marini, P., Onofrj, M., Padovani, A., Stocchi, F., Toni, V., Sampaio, C., Barbosa, E.R., Meco, G., Oostra, B.A., Bonifati, V., 2009. GIGYF2 mutations are not a frequent cause of familial Parkinson's disease. Parkinsonism Relat Disord 15(9), 703-705.

Elbaz, A., Levecque, C., Clavel, J., Vidal, J.S., Richard, F., Correze, J.R., Delemotte, B., Amouyel, P., Alperovitch, A., Chartier-Harlin, M.C., Tzourio, C., 2003. S18Y polymorphism in the UCH-L1 gene and Parkinson's disease: evidence for an age-dependent relationship. Movement disorders : official journal of the Movement Disorder Society 18(2), 130-137.

Foo, J.N., Chew, E.G.Y., Chung, S.J., Peng, R., Blauwendraat, C., Nalls, M.A., Mok, K.Y., Satake, W., Toda, T., Chao, Y., Tan, L.C.S., Tandiono, M., Lian, M.M., Ng, E.Y., Prakash, K.-M., Au, W.L., Meah, W.-Y., Mok, S.Q., Annuar, A.A., Chan, A.Y.Y., Chen, L., Chen, Y., Jeon, B.S., Jiang, L., Lim, J.L., Lin, J.-J., Liu, C., Mao, C., Mok, V., Pei, Z., Shang, H.-F., Shi, C.-H., Song, K., Tan, A.H., Wu, Y.-R., Xu, Y.-m., Xu, R., Yan, Y., Yang, J., Zhang, B., Koh, W.-P., Lim, S.-Y., Khor, C.C., Liu, J., Tan, E.-K., 2020. Identification of Risk Loci for Parkinson Disease in Asians and Comparison of Risk Between Asians and Europeans: A Genome-Wide Association Study. JAMA Neurology.

Foo, J.N., Liany, H., Tan, L.C., Au, W.L., Prakash, K.M., Liu, J., Tan, E.K., 2014. DNAJ mutations are rare in Chinese Parkinson's disease patients and controls. Neurobiol Aging 35(4), 935.e931-932.

Gagliardi, M., Annesi, G., Procopio, R., Morelli, M., Iannello, G., Bonapace, G., Mancini, M., Nicoletti, G., Quattrone, A., 2018. DNAJC13 mutation screening in patients with Parkinson's disease from South Italy. Parkinsonism Relat Disord 55, 134-137.

Guo, Y., Jankovic, J., Zhu, S., Le, W., Song, Z., Xie, W., Liao, D., Yang, H., Deng, H., 2009. GIGYF2 Asn56Ser and Asn457Thr mutations in Parkinson disease patients. Neuroscience letters 454(3), 209-211.

He, Y.C., Huang, P., Li, Q.Q., Sun, Q., Li, D.H., Wang, T., Shen, J.Y., Du, J.J., Cui, S.S., Gao, C., Fu, R., Chen, S.D., 2017. Mutation Analysis of HTRA2 Gene in Chinese Familial Essential Tremor and Familial Parkinson's Disease. Parkinson's disease 2017, 3217474.

Healy, D.G., Abou-Sleiman, P.M., Casas, J.P., Ahmadi, K.R., Lynch, T., Gandhi, S., Muqit, M.M., Foltynie, T., Barker, R., Bhatia, K.P., Quinn, N.P., Lees, A.J., Gibson, J.M., Holton, J.L., Revesz, T., Goldstein, D.B., Wood, N.W., 2006. UCHL-1 is not a Parkinson's disease susceptibility gene. Annals of neurology 59(4), 627-633.

Hughes, A.J., Daniel, S.E., Kilford, L., Lees, A.J., 1992. Accuracy of clinical diagnosis of idiopathic Parkinson's disease: a clinico-pathological study of 100 cases. 55(3), 181-184.

Huo, Z., Luo, X., Zhan, X., Chu, Q., Xu, Q., Yao, J., Pang, H., 2017. Genetic analysis of indel markers in three loci associated with Parkinson's disease. PLoS One 12(9), e0184269.

Jankovic, J., 2008. Parkinson's disease: clinical features and diagnosis. 79(4), 368-376.

Kruger, R., Sharma, M., Riess, O., Gasser, T., Van Broeckhoven, C., Theuns, J., Aasly, J., Annesi, G., Bentivoglio, A.R., Brice, A., Djarmati, A., Elbaz, A., Farrer, M., Ferrarese, C., Gibson, J.M., Hadjigeorgiou, G.M., Hattori, N., Ioannidis, J.P., Jasinska-Myga, B., Klein, C., Lambert, J.C., Lesage, S., Lin, J.J., Lynch, T., Mellick, G.D., de Nigris, F., Opala, G., Prigione, A., Quattrone, 
medRxiv preprint doi: https://doi.org/10.1101/2020.06.26.20141176; this version posted June 28, 2020. The copyright holder for this preprint (which was not certified by peer review) is the author/funder, who has granted medRxiv a license to display the preprint in perpetuity. It is made available under a CC-BY 4.0 International license.

A., Ross, O.A., Satake, W., Silburn, P.A., Tan, E.K., Toda, T., Tomiyama, H., Wirdefeldt, K., Wszolek, Z., Xiromerisiou, G., Maraganore, D.M., 2011. A large-scale genetic association study to evaluate the contribution of Omi/HtrA2 (PARK13) to Parkinson's disease. Neurobiol Aging 32(3), 548.e549-518.

Lautier, C., Goldwurm, S., Durr, A., Giovannone, B., Tsiaras, W.G., Pezzoli, G., Brice, A., Smith, R.J., 2008. Mutations in the GIGYF2 (TNRC15) gene at the PARK11 locus in familial Parkinson disease. Am J Hum Genet 82(4), 822-833.

Lee, S., Emond, M.J., Bamshad, M.J., Barnes, K.C., Rieder, M.J., Nickerson, D.A., Christiani, David C., Wurfel, Mark M., Lin, X., 2012. Optimal Unified Approach for Rare-Variant Association Testing with Application to Small-Sample Case-Control Whole-Exome Sequencing Studies. The American Journal of Human Genetics 91(2), 224-237.

Lek, M., Karczewski, K.J., Minikel, E.V., Samocha, K.E., Banks, E., Fennell, T., O’Donnell-Luria, A.H., Ware, J.S., Hill, A.J., Cummings, B.B., Tukiainen, T., Birnbaum, D.P., Kosmicki, J.A., Duncan, L.E., Estrada, K., Zhao, F., Zou, J., Pierce-Hoffman, E., Berghout, J., Cooper, D.N., Deflaux, N., DePristo, M., Do, R., Flannick, J., Fromer, M., Gauthier, L., Goldstein, J., Gupta, N., Howrigan, D., Kiezun, A., Kurki, M.I., Moonshine, A.L., Natarajan, P., Orozco, L., Peloso, G.M., Poplin, R., Rivas, M.A., Ruano-Rubio, V., Rose, S.A., Ruderfer, D.M., Shakir, K., Stenson, P.D., Stevens, C., Thomas, B.P., Tiao, G., Tusie-Luna, M.T., Weisburd, B., Won, H.H., Yu, D., Altshuler, D.M., Ardissino, D., Boehnke, M., Danesh, J., Donnelly, S., Elosua, R., Florez, J.C., Gabriel, S.B., Getz, G., Glatt, S.J., Hultman, C.M., Kathiresan, S., Laakso, M., McCarroll, S., McCarthy, M.I., McGovern, D., McPherson, R., Neale, B.M., Palotie, A., Purcell, S.M., Saleheen, D., Scharf, J.M., Sklar, P., Sullivan, P.F., Tuomilehto, J., Tsuang, M.T., Watkins, H.C., Wilson, J.G., Daly, M.J., MacArthur, D.G., Exome Aggregation, C., 2016. Analysis of protein-coding genetic variation in 60,706 humans. Nature 536(7616), 285-291.

Lesage, S., Condroyer, C., Lohman, E., Troiano, A., Tison, F., Viallet, F., Damier, P., Tranchant, C., Vidhaillet, M., Ouvrard-Hernandez, A.M., Durr, A., Brice, A., 2010. Follow-up study of the GIGYF2 gene in French families with Parkinson's disease. Neurobiol Aging 31(6), 1069-1071; discussion 1072-1064.

Levecque, C., Destee, A., Mouroux, V., Becquet, E., Defebvre, L., Amouyel, P., Chartier-Harlin, M.C., 2001. No genetic association of the ubiquitin carboxy-terminal hydrolase-L1 gene S18Y polymorphism with familial Parkinson's disease. Journal of neural transmission (Vienna, Austria : 1996) 108(8-9), 979-984.

Li, H., Durbin, R., 2009. Fast and accurate short read alignment with Burrows-Wheeler transform. Bioinformatics 25(14), 1754-1760.

Li, K., Tang, B.S., Guo, J.F., Lou, M.X., Lv, Z.Y., Liu, Z.H., Tian, Y., Song, C.Y., Xia, K., Yan, X.X., 2013. Analysis of EIF4G1 in ethnic Chinese. BMC neurology 13, 38.

Li, L., Funayama, M., Tomiyama, H., Li, Y., Yoshino, H., Sasaki, R., Kokubo, Y., Kuzuhara, S., Mizuno, Y., Hattori, N., 2010. No evidence for pathogenic role of GIGYF2 mutation in Parkinson disease in Japanese patients. Neuroscience letters 479(3), 245-248.

Lin, C.H., Chen, M.L., Chen, G.S., Tai, C.H., Wu, R.M., 2011. Novel variant Pro143Ala in HTRA2 contributes to Parkinson's disease by inducing hyperphosphorylation of HTRA2 protein in mitochondria. Human genetics 130(6), 817-827. 
medRxiv preprint doi: https://doi.org/10.1101/2020.06.26.20141176; this version posted June 28, 2020. The copyright holder for this preprint (which was not certified by peer review) is the author/funder, who has granted medRxiv a license to display the preprint in perpetuity.

It is made available under a CC-BY 4.0 International license.

Lin, C.H., Chen, P.L., Tai, C.H., Lin, H.I., Chen, C.S., Chen, M.L., Wu, R.M., 2019. A clinical and genetic study of early-onset and familial parkinsonism in taiwan: An integrated approach combining gene dosage analysis and next-generation sequencing. Movement disorders : official journal of the Movement Disorder Society 34(4), 506-515.

Lincoln, S., Vaughan, J., Wood, N., Baker, M., Adamson, J., Gwinn-Hardy, K., Lynch, T., Hardy, J., Farrer, M., 1999. Low frequency of pathogenic mutations in the ubiquitin carboxyterminal hydrolase gene in familial Parkinson's disease. Neuroreport 10(2).

Lorenzo-Betancor, O., Ogaki, K., Soto-Ortolaza, A.I., Labbe, C., Walton, R.L., Strongosky, A.J., van Gerpen, J.A., Uitti, R.J., McLean, P.J., Springer, W., Siuda, J., Opala, G., Krygowska-Wajs, A., Barcikowska, M., Czyzewski, K., McCarthy, A., Lynch, T., Puschmann, A., Rektorova, I., Sanotsky, Y., Vilarino-Guell, C., Farrer, M.J., Ferman, T.J., Boeve, B.F., Petersen, R.C., Parisi, J.E., Graff-Radford, N.R., Dickson, D.W., Wszolek, Z.K., Ross, O.A., 2015. DNAJC13 p.Asn855Ser mutation screening in Parkinson's disease and pathologically confirmed Lewy body disease patients. European journal of neurology 22(9), 1323-1325.

Maraganore, D.M., Lesnick, T.G., Elbaz, A., Chartier-Harlin, M.C., Gasser, T., Kruger, R., Hattori, N., Mellick, G.D., Quattrone, A., Satoh, J., Toda, T., Wang, J., Ioannidis, J.P., de Andrade, M., Rocca, W.A., 2004. UCHL1 is a Parkinson's disease susceptibility gene. Annals of neurology 55(4), 512-521.

McKenna, A., Hanna, M., Banks, E., Sivachenko, A., Cibulskis, K., Kernytsky, A., Garimella, K., Altshuler, D., Gabriel, S., Daly, M., DePristo, M.A., 2010. The Genome Analysis Toolkit: A MapReduce framework for analyzing next-generation DNA sequencing data. 20(9), 1297-1303.

Meeus, B., Nuytemans, K., Crosiers, D., Engelborghs, S., Pals, P., Pickut, B., Peeters, K., Mattheijssens, M., Corsmit, E., Cras, P., De Deyn, P.P., Theuns, J., Van Broeckhoven, C., 2011. GIGYF2 has no major role in Parkinson genetic etiology in a Belgian population. Neurobiol Aging 32(2), 308312.

Mellick, G.D., Silburn, P.A., 2000. The ubiquitin carboxy-terminal hydrolase-L1 gene S18Y polymorphism does not confer protection against idiopathic Parkinson's disease. Neuroscience letters 293(2), 127-130.

Momose, Y., Murata, M., Kobayashi, K., Tachikawa, M., Nakabayashi, Y., Kanazawa, I., Toda, T., 2002. Association studies of multiple candidate genes for Parkinson's disease using single nucleotide polymorphisms. 51(1), 133-136.

Nalls, M.A., Blauwendraat, C., Vallerga, C.L., Heilbron, K., Bandres-Ciga, S., Chang, D., Tan, M., Kia, D.A., Noyce, A.J., Xue, A., Bras, J., Young, E., von Coelln, R., Simón-Sánchez, J., Schulte, C., Sharma, M., Krohn, L., Pihlstrøm, L., Siitonen, A., Iwaki, H., Leonard, H., Faghri, F., Gibbs, J.R., Hernandez, D.G., Scholz, S.W., Botia, J.A., Martinez, M., Corvol, J.-C., Lesage, S., Jankovic, J., Shulman, L.M., Sutherland, M., Tienari, P., Majamaa, K., Toft, M., Andreassen, O.A., Bangale, T., Brice, A., Yang, J., Gan-Or, Z., Gasser, T., Heutink, P., Shulman, J.M., Wood, N.W., Hinds, D.A., Hardy, J.A., Morris, H.R., Gratten, J., Visscher, P.M., Graham, R.R., Singleton, A.B., Adarmes-Gómez, A.D., Aguilar, M., Aitkulova, A., Akhmetzhanov, V., Alcalay, R.N., Alvarez, I., Alvarez, V., Bandres-Ciga, S., Barrero, F.J., Bergareche Yarza, J.A., Bernal-Bernal, I., Billingsley, K., Blauwendraat, C., Blazquez, M., Bonilla-Toribio, M., Botía, J.A., Boungiorno, M.T., Bras, J., Brice, A., Brockmann, K., Bubb, V., Buiza-Rueda, D., Cámara, A., Carrillo, F., Carrión-Claro, M., Cerdan, D., Chelban, V., Clarimón, J., Clarke, C., Compta, 
medRxiv preprint doi: https://doi.org/10.1101/2020.06.26.20141176; this version posted June 28, 2020. The copyright holder for this preprint (which was not certified by peer review) is the author/funder, who has granted medRxiv a license to display the preprint in perpetuity. It is made available under a CC-BY 4.0 International license.

Y., Cookson, M.R., Corvol, J.-C., Craig, D.W., Danjou, F., Diez-Fairen, M., Dols-Icardo, O., Duarte, J., Duran, R., Escamilla-Sevilla, F., Escott-Price, V., Ezquerra, M., Faghri, F., Feliz, C., Fernández, M., Fernández-Santiago, R., Finkbeiner, S., Foltynie, T., Gan-Or, Z., Garcia, C., García-Ruiz, P., Gasser, T., Gibbs, J.R., Gomez Heredia, M.J., Gómez-Garre, P., González, M.M., Gonzalez-Aramburu, I., Guelfi, S., Guerreiro, R., Hardy, J., Hassin-Baer, S., Hernandez, D.G., Heutink, P., Hoenicka, J., Holmans, P., Houlden, H., Infante, J., Iwaki, H., Jesús, S., Jimenez-Escrig, A., Kaishybayeva, G., Kaiyrzhanov, R., Karimova, A., Kia, D.A., Kinghorn, K.J., Koks, S., Krohn, L., Kulisevsky, J., Labrador-Espinosa, M.A., Leonard, H.L., Lesage, S., Lewis, P., Lopez-Sendon, J.L., Lovering, R., Lubbe, S., Lungu, C., Macias, D., Majamaa, K., Manzoni, C., Marín, J., Marinus, J., Marti, M.J., Martinez, M., Martínez Torres, I., MartínezCastrillo, J.C., Mata, M., Mencacci, N.E., Méndez-del-Barrio, C., Middlehurst, B., Mínguez, A., Mir, P., Mok, K.Y., Morris, H.R., Muñoz, E., Nalls, M.A., Narendra, D., Noyce, A.J., Ojo, O.O., Okubadejo, N.U., Pagola, A.G., Pastor, P., Perez Errazquin, F., Periñán-Tocino, T., Pihlstrom, L., Plun-Favreau, H., Quinn, J., R'Bibo, L., Reed, X., Rezola, E.M., Rizig, M., Rizzu, P., Robak, L., Rodriguez, A.S., Rouleau, G.A., Ruiz-Martínez, J., Ruz, C., Ryten, M., Sadykova, D., Scholz, S.W., Schreglmann, S., Schulte, C., Sharma, M., Shashkin, C., Shulman, J.M., Sierra, M., Siitonen, A., Simón-Sánchez, J., Singleton, A.B., Suarez-Sanmartin, E., Taba, P., Tabernero, C., Tan, M.X., Tartari, J.P., Tejera-Parrado, C., Toft, M., Tolosa, E., Trabzuni, D., Valldeoriola, F., van Hilten, J.J., Van Keuren-Jensen, K., Vargas-González, L., Vela, L., Vives, F., Williams, N., Wood, N.W., Zharkinbekova, N., Zharmukhanov, Z., Zholdybayeva, E., Zimprich, A., Ylikotila, P., Shulman, L.M., von Coelln, R., Reich, S., Savitt, J., Agee, M., Alipanahi, B., Auton, A., Bell, R.K., Bryc, K., Elson, S.L., Fontanillas, P., Furlotte, N.A., Huber, K.E., Hicks, B., Jewett, E.M., Jiang, Y., Kleinman, A., Lin, K.-H., Litterman, N.K., McCreight, J.C., McIntyre, M.H., McManus, K.F., Mountain, J.L., Noblin, E.S., Northover, C.A.M., Pitts, S.J., Poznik, G.D., Sathirapongsasuti, J.F., Shelton, J.F., Shringarpure, S., Tian, C., Tung, J., Vacic, V., Wang, X., Wilson, C.H., Anderson, T., Bentley, S., Dalrymple-Alford, J., Fowdar, J., Gratten, J., Halliday, G., Henders, A.K., Hickie, I., Kassam, I., Kennedy, M., Kwok, J., Lewis, S., Mellick, G., Montgomery, G., Pearson, J., Pitcher, T., Sidorenko, J., Silburn, P.A., Vallerga, C.L., Visscher, P.M., Wallace, L., Wray, N.R., Xue, A., Yang, J., Zhang, F., 2019. Identification of novel risk loci, causal insights, and heritable risk for Parkinson's disease: a meta-analysis of genome-wide association studies. The Lancet Neurology 18(12), 1091-1102.

Nichols, W.C., Kissell, D.K., Pankratz, N., Pauciulo, M.W., Elsaesser, V.E., Clark, K.A., Halter, C.A., Rudolph, A., Wojcieszek, J., Pfeiffer, R.F., Foroud, T., 2009. Variation in GIGYF2 is not associated with Parkinson disease. Neurology 72(22), 1886-1892.

Nishioka, K., Funayama, M., Vilarino-Guell, C., Ogaki, K., Li, Y., Sasaki, R., Kokubo, Y., Kuzuhara, S., Kachergus, J.M., Cobb, S.A., Takahashi, H., Mizuno, Y., Farrer, M.J., Ross, O.A., Hattori, N., 2014. EIF4G1 gene mutations are not a common cause of Parkinson's disease in the Japanese population. Parkinsonism Relat Disord 20(6), 659-661.

Nuytemans, K., Bademci, G., Inchausti, V., Dressen, A., Kinnamon, D.D., Mehta, A., Wang, L., Zuchner, S., Beecham, G.W., Martin, E.R., Scott, W.K., Vance, J.M., 2013. Whole exome sequencing of rare variants in EIF4G1 and VPS35 in Parkinson disease. Neurology 80(11), 982989.

Postuma, R.B., Berg, D., Stern, M., Poewe, W., Olanow, C.W., Oertel, W., Obeso, J., Marek, K., Litvan, I., Lang, A.E., Halliday, G., Goetz, C.G., Gasser, T., Dubois, B., Chan, P., Bloem, B.R., Adler, 
medRxiv preprint doi: https://doi.org/10.1101/2020.06.26.20141176; this version posted June 28, 2020. The copyright holder for this preprint (which was not certified by peer review) is the author/funder, who has granted medRxiv a license to display the preprint in perpetuity.

It is made available under a CC-BY 4.0 International license .

C.H., Deuschl, G., 2015. MDS clinical diagnostic criteria for Parkinson's disease. 30(12), 15911601.

Purcell, S., Neale, B., Todd-Brown, K., Thomas, L., Ferreira, M.A.R., Bender, D., Maller, J., Sklar, P., de Bakker, P.I.W., Daly, M.J., Sham, P.C., 2007. PLINK: A Tool Set for Whole-Genome Association and Population-Based Linkage Analyses. The American Journal of Human Genetics 81(3), 559-575.

Ragland, M., Hutter, C., Zabetian, C., Edwards, K., 2009. Association between the ubiquitin carboxylterminal esterase L1 gene (UCHL1) S18Y variant and Parkinson's Disease: a HuGE review and meta-analysis. American journal of epidemiology 170(11), 1344-1357.

Ross, J.P., Dupre, N., Dauvilliers, Y., Strong, S., Ambalavanan, A., Spiegelman, D., Dionne-Laporte, A., Pourcher, E., Langlois, M., Boivin, M., Leblond, C.S., Dion, P.A., Rouleau, G.A., Gan-Or, Z., 2016. Analysis of DNAJC13 mutations in French-Canadian/French cohort of Parkinson's disease. Neurobiol Aging 45, 212.e213-212.e217.

Ross, O.A., Soto, A.I., Vilarino-Guell, C., Heckman, M.G., Diehl, N.N., Hulihan, M.M., Aasly, J.O., Sando, S., Gibson, J.M., Lynch, T., Krygowska-Wajs, A., Opala, G., Barcikowska, M., Czyzewski, K., Uitti, R.J., Wszolek, Z.K., Farrer, M.J., 2008. Genetic variation of Omi/HtrA2 and Parkinson's disease. Parkinsonism Relat Disord 14(7), 539-543.

Samaranch, L., Lorenzo, E., Pastor, M.A., Riverol, M., Luquin, M.R., Rodriguez-Oroz, M.C., Obeso, J.A., Pastor, P., 2010. Analysis of the GIGYF2 gene in familial and sporadic Parkinson disease in the Spanish population. European journal of neurology 17(2), 321-325.

Satoh, J., Kuroda, Y., 2001. A polymorphic variation of serine to tyrosine at codon 18 in the ubiquitin C-terminal hydrolase-L1 gene is associated with a reduced risk of sporadic Parkinson's disease in a Japanese population. Journal of the neurological sciences 189(1-2), 113-117.

Savettieri, G., De Marco, E.V., Civitelli, D., Salemi, G., Nicoletti, G., Annesi, G., Ciro Candiano, I.C., Quattrone, A., 2001. Lack of association between ubiquitin carboxy-terminal hydrolase L1 gene polymorphism and PD. Neurology 57(3), 560-561.

Schulte, E.C., Mollenhauer, B., Zimprich, A., Bereznai, B., Lichtner, P., Haubenberger, D., Pirker, W., Brucke, T., Molnar, M.J., Peters, A., Gieger, C., Trenkwalder, C., Winkelmann, J., 2012. Variants in eukaryotic translation initiation factor 4G1 in sporadic Parkinson's disease. Neurogenetics 13(3), 281-285.

Siitonen, A., Majounie, E., Federoff, M., Ding, J., Majamaa, K., Singleton, A.B., 2013. Mutations in EIF4G1 are not a common cause of Parkinson's disease. European journal of neurology 20(4), e59.

Simon-Sanchez, J., Singleton, A.B., 2008. Sequencing analysis of OMI/HTRA2 shows previously reported pathogenic mutations in neurologically normal controls. Hum Mol Genet 17(13), 19881993.

Strauss, K.M., Martins, L.M., Plun-Favreau, H., Marx, F.P., Kautzmann, S., Berg, D., Gasser, T., Wszolek, Z., Muller, T., Bornemann, A., Wolburg, H., Downward, J., Riess, O., Schulz, J.B., Kruger, R., 2005. Loss of function mutations in the gene encoding Omi/HtrA2 in Parkinson's disease. Hum Mol Genet 14(15), 2099-2111. 
medRxiv preprint doi: https://doi.org/10.1101/2020.06.26.20141176; this version posted June 28, 2020. The copyright holder for this preprint (which was not certified by peer review) is the author/funder, who has granted medRxiv a license to display the preprint in perpetuity. It is made available under a CC-BY 4.0 International license.

Sudhaman, S., Behari, M., Govindappa, S.T., Muthane, U.B., Juyal, R.C., Thelma, B.K., 2013. VPS35 and EIF4G1 mutations are rare in Parkinson's disease among Indians. Neurobiol Aging 34(10), 2442.e2441-2443.

Sun, S., Zhao, Y., Jin, G., Kang, H., 2014. Lack of association between UCHL1 S18Y gene polymorphism and Parkinson's disease in the Asian population: a meta-analysis. Neurological sciences : official journal of the Italian Neurological Society and of the Italian Society of Clinical Neurophysiology 35(12), 1867-1876.

Tan, E.K., Lin, C.H., Tai, C.H., Tan, L.C., Chen, M.L., Li, R., Lim, H.Q., Pavanni, R., Yuen, Y., Prakash, K.M., Zhao, Y., Wu, R.M., 2009. Non-synonymous GIGYF2 variants in Parkinson's disease from two Asian populations. Human genetics 126(3), 425-430.

Tan, E.K., Schapira, A.H., 2010. Summary of GIGYF2 studies in Parkinson's disease: the burden of proof. European journal of neurology 17(2), 175-176.

Tian, J.Y., Guo, J.F., Wang, L., Sun, Q.Y., Yao, L.Y., Luo, L.Z., Shi, C.H., Hu, Y.C., Yan, X.X., Tang, B.S., 2012. Mutation analysis of LRRK2, SCNA, UCHL1, HtrA2 and GIGYF2 genes in Chinese patients with autosomal dorminant Parkinson's disease. Neuroscience letters 516(2), 207-211.

Tran, H.H., Dang, S.N.A., Nguyen, T.T., Huynh, A.M., Dao, L.M., Kamei, K., Yamaguchi, M., Dang, T.T.P., 2018. Drosophila Ubiquitin C-Terminal Hydrolase Knockdown Model of Parkinson's Disease. Scientific reports 8(1), 4468.

Tucci, A., Charlesworth, G., Sheerin, U.M., Plagnol, V., Wood, N.W., Hardy, J., 2012. Study of the genetic variability in a Parkinson's Disease gene: EIF4G1. Neuroscience letters 518(1), 19-22.

Unal Gulsuner, H., Gulsuner, S., Mercan, F.N., Onat, O.E., Walsh, T., Shahin, H., Lee, M.K., Dogu, O., Kansu, T., Topaloglu, H., Elibol, B., Akbostanci, C., King, M.C., Ozcelik, T., Tekinay, A.B., 2014. Mitochondrial serine protease HTRA2 p.G399S in a kindred with essential tremor and Parkinson disease. Proceedings of the National Academy of Sciences of the United States of America 111(51), 18285-18290.

Vilariño-Güell, C., Rajput, A., Milnerwood, A.J., Shah, B., Szu-Tu, C., Trinh, J., Yu, I., Encarnacion, M., Munsie, L.N., Tapia, L., Gustavsson, E.K., Chou, P., Tatarnikov, I., Evans, D.M., Pishotta, F.T., Volta, M., Beccano-Kelly, D., Thompson, C., Lin, M.K., Sherman, H.E., Han, H.J., Guenther, B.L., Wasserman, W.W., Bernard, V., Ross, C.J., Appel-Cresswell, S., Stoessl, A.J., Robinson, C.A., Dickson, D.W., Ross, O.A., Wszolek, Z.K., Aasly, J.O., Wu, R.-M., Hentati, F., Gibson, R.A., McPherson, P.S., Girard, M., Rajput, M., Rajput, A.H., Farrer, M.J., 2013. DNAJC13 mutations in Parkinson disease. Human Molecular Genetics 23(7), 1794-1801.

Vilarino-Guell, C., Ross, O.A., Soto, A.I., Farrer, M.J., Haugarvoll, K., Aasly, J.O., Uitti, R.J., Wszolek, Z.K., 2009. Reported mutations in GIGYF2 are not a common cause of Parkinson's disease. Movement disorders : official journal of the Movement Disorder Society 24(4), 619-620.

Wang, C.Y., Xu, Q., Weng, L., Zhang, Q., Zhang, H.N., Guo, J.F., Tan, L.M., Tang, J.G., Yan, X.X., Tang, B.S., 2011. Genetic variations of Omi/HTRA2 in Chinese patients with Parkinson's disease. Brain research 1385, 293-297.

Wang, J., Zhao, C.Y., Si, Y.M., Liu, Z.L., Chen, B., Yu, L., 2002. ACT and UCH-L1 polymorphisms in Parkinson's disease and age of onset. Movement disorders : official journal of the Movement Disorder Society 17(4), 767-771. 
medRxiv preprint doi: https://doi.org/10.1101/2020.06.26.20141176; this version posted June 28, 2020. The copyright holder for this preprint (which was not certified by peer review) is the author/funder, who has granted medRxiv a license to display the preprint in perpetuity.

It is made available under a CC-BY 4.0 International license .

Wang, K., Li, M., Hakonarson, H., 2010. ANNOVAR: functional annotation of genetic variants from high-throughput sequencing data. Nucleic Acids Research 38(16), e164-e164.

Wang, L., Guo, J.F., Zhang, W.W., Xu, Q., Zuo, X., Shi, C.H., Luo, L.Z., Liu, J., Hu, L., Hu, Y.C., She, L., Jiang, H., Yan, X.X., Xia, K., Pan, Q., Tang, B.S., 2010. Novel GIGYF2 gene variants in patients with Parkinson's disease in Chinese population. Neuroscience letters 473(2), 131-135.

Wang, L., Guo, J.F., Zhang, W.W., Xu, Q., Zuo, X., Shi, C.H., Luo, L.Z., Liu, J., Hu, L., Hu, Y.C., Yan, X.X., Tang, B.S., 2011. Follow-up study of variants of the GIGYF2 gene in Chinese patients with Parkinson's disease. Journal of clinical neuroscience : official journal of the Neurosurgical Society of Australasia 18(12), 1699-1701.

Wintermeyer, P., Kruger, R., Kuhn, W., Muller, T., Woitalla, D., Berg, D., Becker, G., Leroy, E., Polymeropoulos, M., Berger, K., Przuntek, H., Schols, L., Epplen, J.T., Riess, O., 2000. Mutation analysis and association studies of the UCHL1 gene in German Parkinson's disease patients. Neuroreport 11(10), 2079-2082.

Yang, N., Zhao, Y., Liu, Z., Zhang, R., He, Y., Zhou, Y., Xu, Q., Sun, Q., Yan, X., Guo, J., Tang, B., 2019. Systematically analyzing rare variants of autosomal-dominant genes for sporadic Parkinson's disease in a Chinese cohort. Neurobiology of Aging 76, 215.e211-215.e217.

Zhang, J., Hattori, N., Leroy, E., Morris, H.R., Kubo, S., Kobayashi, T., Wood, N.W., Polymeropoulos, M.H., Mizuno, Y., 2000. Association between a polymorphism of ubiquitin carboxy-terminal hydrolase L1 (UCH-L1) gene and sporadic Parkinson's disease. Parkinsonism Relat Disord 6(4), 195-197.

Zhang, Y., Sun, Q.Y., Yu, R.H., Guo, J.F., Tang, B.S., Yan, X.X., 2015. The contribution of GIGYF2 to Parkinson's disease: a meta-analysis. Neurological sciences : official journal of the Italian Neurological Society and of the Italian Society of Clinical Neurophysiology 36(11), 2073-2079.

Zhang, Y., Zheng, L., Zhang, T., Wang, Y., Xiao, Q., Fei, Q.Z., Cui, P.J., Cao, L., Chen, S.D., 2009. GIGYF2 Asn56Ser mutation is rare in Chinese Parkinson's disease patients. Neuroscience letters 463(3), 172-175.

Zhao, Y., Ho, P., Prakash, K.M., Foo, J.N., Liu, J.J., Au, W.L., Tan, L.C., Tan, E.K., 2013. Analysis of EIF4G1 in Parkinson's disease among Asians. Neurobiol Aging 34(4), 1311.e1315-1316.

Zimprich, A., Schulte, C., Reinthaler, E., Haubenberger, D., Balzar, J., Lichtner, P., El Tawil, S., Edris, S., Foki, T., Pirker, W., Katzenschlager, R., Daniel, G., Brucke, T., Auff, E., Gasser, T., 2009. PARK11 gene (GIGYF2) variants Asn56Ser and Asn457Thr are not pathogenic for Parkinson's disease. Parkinsonism Relat Disord 15(7), 532-534. 
medRxiv preprint doi: https://doi.org/10.1101/2020.06.26.20141176; this version posted June 28, 2020. The copyright holder for this preprint (which was not certified by peer review) is the author/funder, who has granted medRxiv a license to display the preprint in perpetuity.

It is made available under a CC-BY 4.0 International license .

\begin{tabular}{|c|c|c|c|c|c|c|c|c|c|c|c|}
\hline \multirow[t]{2}{*}{$\begin{array}{l}\text { Depth of } \\
\text { coverage }\end{array}$} & \multirow{2}{*}{ Gene } & \multicolumn{2}{|c|}{ All rare } & \multicolumn{2}{|c|}{ Rare CADD } & \multicolumn{2}{|c|}{ Rare functional } & \multicolumn{2}{|c|}{$\begin{array}{c}\text { Rare } \\
\text { nonsynonymous }\end{array}$} & \multicolumn{2}{|c|}{$\begin{array}{l}\text { Rare loss-of- } \\
\text { function }\end{array}$} \\
\hline & & SKAT-O & $\begin{array}{l}\text { SKAT } \\
\text { Burden }\end{array}$ & SKAT-O & $\begin{array}{l}\text { SKAT } \\
\text { Burden }\end{array}$ & SKAT-O & $\begin{array}{l}\text { SKAT } \\
\text { Burden }\end{array}$ & SKAT-O & $\begin{array}{l}\text { SKAT } \\
\text { Burden }\end{array}$ & SKAT-O & $\begin{array}{l}\text { SKAT } \\
\text { Burden }\end{array}$ \\
\hline \multirow[t]{18}{*}{$30 x$} & \multicolumn{11}{|c|}{ McGill } \\
\hline & DNAJC13 & 0.7274 & 0.4935 & 0.9052 & 1.0000 & 0.8449 & 0.6467 & 0.8987 & 0.8001 & NV & NV \\
\hline & EIF4G1 & 0.7330 & 0.8183 & 0.6368 & 0.9859 & 0.5659 & 0.8356 & 0.8719 & 0.6904 & 0.3153 & 1.0000 \\
\hline & GIGYF2 & 0.2543 & 0.2358 & 0.2366 & 0.4767 & 0.1037 & 0.0750 & 0.3201 & 0.6587 & 0.8845 & 0.8539 \\
\hline & HTRA2 & 0.5922 & 0.3411 & 0.7980 & 0.7980 & 0.2923 & 0.5129 & 0.2228 & 0.2228 & 0.6114 & 0.6114 \\
\hline & UCHL1 & 0.8267 & 1.0000 & 0.7288 & 0.3405 & 0.5023 & 1.0000 & 0.4795 & 0.3130 & NV & NV \\
\hline & \multicolumn{11}{|c|}{ Columbia } \\
\hline & DNAJC13 & 0.7085 & 0.4927 & 0.3437 & 0.2061 & 0.5000 & 0.3173 & 0.5935 & 0.3928 & NV & NV \\
\hline & EIF4G1 & 0.5109 & 0.3411 & 0.9826 & 0.8615 & 0.3835 & 0.2392 & 0.6344 & 0.4288 & 0.4060 & 0.7585 \\
\hline & GIGYF2 & 0.7827 & 0.5762 & 0.6380 & 0.5549 & 0.7934 & 0.6399 & 0.8887 & 0.7576 & 0.5551 & 0.5836 \\
\hline & HTRA2 & 0.2764 & 0.3233 & 0.3438 & 0.7742 & 0.8353 & 0.8353 & 0.3438 & 0.7742 & NV & NV \\
\hline & $U C H L 1$ & 0.7508 & 0.7154 & 0.9283 & 0.7706 & 0.8912 & 0.7413 & 0.7805 & 0.5467 & NV & NV \\
\hline & \multicolumn{11}{|c|}{ Sheba } \\
\hline & DNAJC13 & 0.0423 & 0.5694 & 0.0024 & 0.2642 & 0.0014 & 0.1520 & 0.0013 & 0.1174 & NV & NV \\
\hline & EIF4G1 & 0.7028 & 0.4890 & 0.5436 & 0.6780 & 0.6174 & 0.5828 & 0.6353 & 0.6881 & 0.1026 & 0.1026 \\
\hline & GIGYF2 & 0.2781 & 0.2030 & 0.8367 & 0.7090 & 0.1977 & 0.2324 & 0.6536 & 0.4732 & 0.1654 & 0.1593 \\
\hline & HTRA2 & 0.0661 & 0.0803 & 0.0463 & 0.0463 & 0.2641 & 0.1382 & 0.0463 & 0.0463 & NV & NV \\
\hline & $U C H L 1$ & 0.4786 & 0.3435 & 0.8450 & 0.8450 & 0.5739 & 0.3347 & 0.9178 & 0.7945 & 1.0000 & 1.0000 \\
\hline \multirow[t]{18}{*}{$50 x$} & \multicolumn{11}{|c|}{ McGill } \\
\hline & DNAJC13 & 0.6015 & 0.5437 & 0.3990 & 1.0000 & 0.4100 & 0.8328 & 0.4158 & 0.8600 & NV & NV \\
\hline & EIF4G1 & 0.4384 & 1.0000 & 0.8636 & 0.8636 & 0.2985 & 1.0000 & 0.9448 & 0.8344 & 0.2413 & 0.8701 \\
\hline & GIGYF2 & 0.3312 & 0.3512 & 0.1292 & 0.9995 & 0.0933 & 0.1360 & 0.1628 & 0.7996 & 0.8448 & 0.8448 \\
\hline & HTRA2 & NV & NV & NV & NV & NV & NV & NV & NV & NV & NV \\
\hline & $U C H L 1$ & 0.4345 & 0.2882 & 0.7152 & 0.7152 & 0.2815 & 0.1934 & 0.2815 & 0.1934 & NV & NV \\
\hline & \multicolumn{11}{|c|}{ Columbia } \\
\hline & DNAJC13 & 0.6194 & 0.4114 & 0.3587 & 0.2184 & 0.3861 & 0.2361 & 0.5021 & 0.3224 & NV & NV \\
\hline & EIF4G1 & 0.5684 & 0.5900 & NV & NV & 0.3289 & 0.9888 & NV & NV & 0.3314 & 0.3314 \\
\hline & GIGYF2 & 0.3701 & 0.2280 & 0.4528 & 0.2644 & 0.3080 & 0.1814 & 0.6180 & 0.4336 & 0.2021 & 0.1348 \\
\hline & HTRA2 & NV & NV & NV & NV & NV & NV & NV & NV & NV & NV \\
\hline & UCHL1 & 0.5247 & 0.6941 & 0.4676 & 0.3779 & 0.6953 & 0.9221 & 0.6953 & 0.9221 & NV & NV \\
\hline & \multicolumn{11}{|c|}{ Sheba } \\
\hline & DNAJC13 & 0.0426 & 0.1512 & 0.0002 & 0.1323 & 0.0005 & 0.1389 & 0.0002 & 0.1323 & NV & NV \\
\hline & EIF4G1 & 0.6150 & 0.3688 & 0.7538 & 0.7538 & 0.7538 & 0.7538 & 0.7538 & 0.7538 & NV & NV \\
\hline & GIGYF2 & 0.6256 & 0.4155 & 0.6067 & 0.4443 & 0.5098 & 0.3352 & 0.7803 & 0.6084 & NV & NV \\
\hline & HTRA2 & NV & NV & NV & NV & NV & NV & NV & NV & NV & NV \\
\hline & UCHL1 & 0.5455 & 0.3953 & 0.8472 & 0.8472 & 0.9166 & 0.7915 & 0.9166 & 0.7915 & NV & NV \\
\hline
\end{tabular}

Abbreviations: SKAT: Sequence Kernel Association Test; SKAT-O: Optimized Sequence Kernel Association Test; CADD: Combined Annotation Dependent Depletion; NV: No Variant

Table 1: SKAT-O and burden analysis results for each gene, across cohort and coverage depth for mutation type 